\title{
The Effect of Hemostatic Method on Ovarian Reserve following Endometrioma Excision
}

\author{
Vasilios Tanos $^{1 *}$ and Sayed El Akhras ${ }^{2}$ \\ ${ }^{1}$ Medical School, Nicosia University, Egypt \\ ${ }^{2}$ Director of the Department of Gynecology, Omam Hospital, Egypt
}

Submission: May 15, 2017; Published: May 30, 2017

*Corresponding author: Vasilios Tanos, Medical School, Nicosia University, Cyprus, Tel: +35799683488; Fax: +35799512371;

Email: v.tanos@aretaeio.com

\section{Abstract}

Endometrioma surgery and hemostasis negative affect ovarian reserve. The size of the endometrioma and the surgical technique are the most determining factors preserving ovarian function. Stripping the endometrioma pseudocapsule is detrimental for healthy ovarian tissue, reduces the risk of recurrence, however, not appropriate for infertility patients undergoing ART. Fenestration and laser vaporization of an endometrioma seems to minimally destruct the healthy ovarian tissue, offering the best surgical treatment option to infertility patients.

Keywords: Cystectomy; Endometrioma; Hemostasis; Ovarian reserve; Antral follicle count

Abbreviations: AFC: Antral Follicle Count; AMH: Anti-Mullerian Hormone; ART: Assisted Reproductive Technology; DGGG: Deutsche GesellschaftfürGynäkologie und Geburtshilfe eV (The German Society for Gynecology and Obstetrics eV); E2: Estradiol; FSH: FollicleStimulating Hormone; IVF: In Vitro Fertilization; LH: Luteinizing Hormone; MOD: Mean Ovarian Diameter; PRCTs: Prospective Randomized Clinical Trial; RCTs: Randomized Clinical Trial

\section{Background}

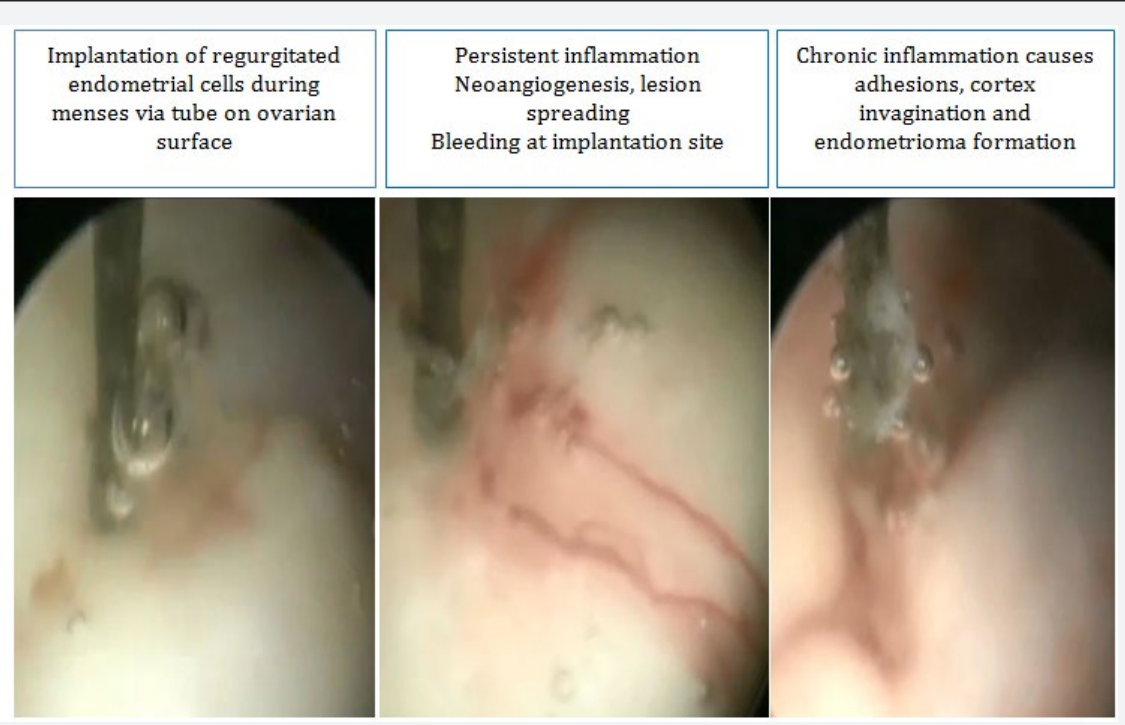

Figure 1: The generation of an ovarian endometrioma as observed in Trans Vaginal Hydrolaparoscopy confirming Sampson hypothesis for pathogenesis.

a. Implantation of regurgitated endometrial cells during menses via tube on ovarian surface

b. Persistent inflammation Neoangiogenesis, lesion spreading Bleeding at implantation site

c. Chronic inflammation causes adhesions, cortex invagination and endometrioma formation 


\section{$2 \mathrm{~cm}$ endom/oma ablation using THVL bipolar energy}

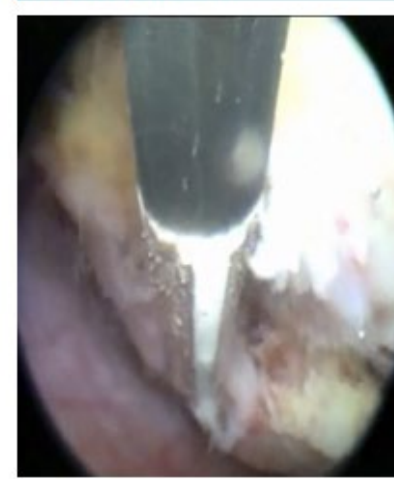

Endometrioma pseudocapsule
After endometrioma excision and ablation, completely cures ovarian epithelium, and reappears normal with pinkish color

Figure 2: Treatment of a $2 \mathrm{~cm}$ ovarian endometrioma by Trans Vaginal Hydro-laparoscopy at a very early stage confirms the development of pseudocapsule which is actually the ovarian cortex.

\section{a . $2 \mathrm{~cm}$ endom/oma ablation using THVL bipolar energy \\ b. Endometrioma pseudocapsule}

c. After endometrioma excision and ablation, completely cures ovarian epithelium, and reappears normal with pinkish color

Endometrioma develops from the ovarian epithelium, hence affects in general ovarian function but especially folliculogenesis [1]. Decreased antral follicle count (AFC) and reduction in the number of oocytes retrieved during IVF have been repeatedly reported [2-5]. Ovarian endometriosis is often a marker for more extensive pelvic and intestinal disease [6] Trans-vaginal hydrolaproscopy elucidates the pathogenesis and can provide the treatment of small ovarian endometrioma upto $3 \mathrm{~cm}$ [1]. Implantation of regurgitated endometrial cells via tubal lumen during menses on ovarian surface causes persistent inflammation, bleeding at implantation site and invagination of the ovarian cortex, adhesions, cystic formation, tissue alterations and deformity (Figure 1) hence, the endometrioma pseudocapsule is actually the ovarian epithelium with the follicular structures and oocytes. Once an endometrioma is open after thorough irrigation, careful endoscopic close up image reveals scanty areas of pinkish tissue which is actually the ovarian epithelium. Of course the majority of the exposed tissue is embedded with endometriotic cells that will be destroyed, usually by an effort of stripping the capsule or bipolar coagulation, laser etc.

Among patients with endometriosis 17-44\% have endometriomas [7-9], whereas more frequently located on the

left ovary $[10,11]$ Medical treatments lead only to a temporary volume reduction [12] while drainage leads to a quick recurrence and increases the risk of abscess [13] Surgery is the only way to treat endometrioma (DGGG). Extensive endometrioma surgery by stripping or ablation of the pseudocapsule offers low recurrence rate however, healthy ovarian tissue is destroyed which is vital for patients under fertility treatment [14]. When no stripping is performed and electrocoagulation is applied with caution the recurrence rate can be $9.6-45 \%$ [15] It is also quite debatable whether cytoreductive methods like laser, plasma and bipolar energies and suturing are all equally detrimental to healthy ovarian tissue found below an endometrioma.

In this article we review the impact of endometrioma surgery and haemostasis technique on the ovarian reserves. Pub Med literature review for facts, views and news about endometrioma surgical technique and hemostatic method preserving ovarian healthy tissue and reserves was performed. Ovarian reserves are compromised during endometrioma surgery; many prospective cohort studies have shown the detrimental action of endometrioma excision by stripping technique and diathermy as haemostatic method on ovarian reserves. Uncu et al. [16] compared the $\mathrm{AMH}$ and $\mathrm{AFC}$ results before and after surgery in 30 patients with endometrioma and 30 patients with simple ovarian cysts. There was a significant reduction in both markers in endometrioma group. Another prospective study by Chen et al. [17] compared 40 patients with endometrioma to 22 patients with benign ovarian cysts and 38 infertility patients with tubal infertility. The AMH was significantly reduced in endometioma excision cases while in the other 2 groups results were similar and not affected by surgery AMH measured in $\mathrm{ng} / \mathrm{ml}$ fluctuated to $1.53 \pm 1.37$ in endometrioma cases, $2.20 \pm 1.23$ in benign cysts and $2.82 \pm 1.74$ in patients with tubal factor.

\section{Markers of ovarian reserve}

The Anti mullerian Hormone (AMH), FSH, LH, E2 levels and Inhibin as biomarkers, the antral follicular count (AFC), ovarian 
volume and diameter as sonographic markers have all been reported as indicators for ovarian reserves. A comparative $\mathrm{AMH}$ level and AFC of low fertility potential usually referred to "poor responders" which according to Bologna criteria are defined when AMH is $0.5-1.1 \mathrm{ng} / \mathrm{ml}$ and AFC 5-7 follicles [18] An AMH of $2 \mathrm{ng} / \mathrm{ml}$ is considered as abnormal in women aged $<30$ years old [19] indicating the decreased overall number of oocytes but not the ability of an ovum to reach fertilization and pregnancy.

Among all biological and clinical markers for ovarian reserves $\mathrm{AMH}$ and $\mathrm{AFC}$ are considered the most reliable measurements. AMH has similar correlation with primordial follicle count and similar capacity for predicting ovarian response to stimulation [20-22] Inter-cycle and intra-individual variation of $\mathrm{AMH}$ is significantly less than that of AFC in several studies [23] AFC is less reliable than AMH because antral follicles may be obscured by an endometrioma leading to underestimation of AFC pre and post operatively, however $\mathrm{AMH}$ samples are stable at $-70{ }^{\circ} \mathrm{C}$ to $-80^{\circ} \mathrm{C}$ which makes storage difficult while most of the studies do not report the AMH specimens handling process [24].

A letter to the Editor in 2014 in the journal of Human Reproduction about meta-analysis weakness [25] 1/8 studies by Raffi et al. reported storing samples at $-20{ }^{\circ} \mathrm{C}$ while samples were either analyzed directly without cryostorage [26,27] or were stored at -70 or $-80^{\circ} \mathrm{C}$ before actual measurements in the remain 5 studies [28-31] In addition, the impact of surgery type on ovarian reserves involves several biases such as the age of the patients, persistence, size, location and bilaterality of the endometrioma. Concomitant pathologies like adhesions, endometriosis, tubal and fossa ovarica status, training and experience of surgeon, type of surgery technique used (biopsy, stripping, excision) and type of haemostasis used (Bipolar, Suturing, Laser, Sealants) all are variables that can influence $\mathrm{AMH}$ results.

\section{AMH levels after endometrioma excision}

Significant decline in serum AMH levels 1-3 months after endometrioma excision [32]. Progressive decline in AMH levels in two studies during 6 months after excision and [33,34] persistent decline in AMH during and after 6 months after endometrioma excision have been reported [24,25] Bilateral excision causes a greater decline in serum AMH levels than unilateral $[16,29]$ Second surgery for recurrent unilateral endometrioma causes even lower AMH levels and AFC of the affected ovary than before surgery as reported by [11] However, the number of ovarian follicles on surgical specimens did not correlate with the decline in serum AMH levels $[16,29,33]$ Damage to the ovarian circulation could be the most important determinant of the loss of ovarian reserve, Especially bipolar dissection near the ovarian hilus.
The selection of haemostatic method is crucial for ovarian reserves Statistical comparison between post-operative mean values of AFC (antral follicular count) PSV (Peak Systolic Velocity) and MOD (Mean ovarian diameter) on TVS examinations comparing long term impact on ovarian reserve between laparoscopic ovarian cystectomy and bipolar coagulation and open laparotomy and suturing for ovarian endometrioma, demonstrated significantly better ovarian reserves in favour to laparotomy group. It was noted that the damage, cannot be ascribed only to the amount of ovarian tissue removed during surgery but also to the possible damage of the ovarian vascular system by electrocoagulation [35].

The impact of electrocoagulation on ovarian reserve was investigated in 191 patients by a prospective randomized study, Group 1 underwent laparoscopic ovarian cystectomy by coagulation or harmonic scalpel and a second group of patients operated by laparotomy and suturing of the cyst bed. After 12 months of follow up In electrocoagulation group, FSH was over $10 \mathrm{IU} / \mathrm{L}$ and AFC and mean ovarian diameter(MOD) were significantly reduced [36]. Comparing ovarian reserve after laparoscopic excision of endometrioma cysts and hemostasis achieved either by bipolar coagulation or suturing a randomized clinical trial by Asgari Z, et al. [37] concluded that stripping of endometrioma pseudo-capsule reduces ovarian reserve, regardless of the hemostatic methods used. Intracorporeal suturing showed less damage on ovarian reserve as compared to bipolar electrocoagulation.

Minimal invasive surgery of 67 endometrioma and 62 non endometrioma ovarian cysts, the $\mathrm{AMH}$ in 43 patients treated with bipolar drop by $41.2 \%$ while in 86 patients haemostasis achieved with sealants drop by $15.4 \%(\mathrm{P}=0.003)$ [38].

In 10 ovarian endometriomas of $>30 \mathrm{~mm}$, managed by complete vaporization of the inner surface using plasma energy followed by cystectomy. Histologic evaluation of the effectiveness of endometrial tissue ablation and depth of necrosis followed. Plasma energy ablation of endometrial tissue found to cause minimal damage to the ovarian parenchyma [39]. The same authors operated 15 endometrioma ablation using plasma energy and 15 ovarian tissue-sparing cystectomies comparing by 3D ultrasound ovarian volume and AFC pre- and post-operative results. Those who underwent cystectomy showed a statistically significant reduction in ovarian volume and AFC when compared with women who underwent ablation using plasma energy. This technique seems to be attractive for reproductive surgery, especially for women with risk for postoperative ovarian reserve impairment, bilateral endometriomas and premature ovarian failure [40]. 
Table 1: Unilateral Endometrioma Surgery and Haemostasis techniques

\begin{tabular}{|c|c|c|c|c|c|c|c|}
\hline Author & Refer & Study Type & $\begin{array}{l}\text { Endoma Uni- } \\
\text { lateral }\end{array}$ & $\begin{array}{l}\text { Haemostasis } \\
\text { Technique }\end{array}$ & Marker & Pop Mths & P Value \\
\hline $\begin{array}{c}\text { Kitajima et al. } \\
{[30]}\end{array}$ & FS 2011 & Prospective & $\begin{array}{c}19 \text { Vs } \\
13 \text { Bg cysts }\end{array}$ & Stripping only & AMH & 3 & $\begin{array}{l}\text { Significantly } \\
\text { Higher }\end{array}$ \\
\hline $\begin{array}{l}\text { Lee DY et al. } \\
\text { [31] }\end{array}$ & Gyn Endoc 2010 & Prospective & $\begin{array}{c}13 \text { excisio } \\
14\end{array}$ & $\begin{array}{l}\text { Bipolar Oopho- } \\
\text { rectom }\end{array}$ & $\begin{array}{l}\text { AMH } \\
\text { AMH }\end{array}$ & 1,3 & $\begin{array}{l}0.001 \\
0.002\end{array}$ \\
\hline $\begin{array}{c}\text { Zaitoun } \mathrm{M} \text { et al. } \\
\text { [35] }\end{array}$ & J Ov Res 2013 & Prospective & $\begin{array}{l}61 \\
60\end{array}$ & $\begin{array}{l}\text { Lpic Bipolar } \\
\text { Lmy suturing }\end{array}$ & $\begin{array}{l}\text { AMH, } \\
\text { FSH }\end{array}$ & $6,8,12$ & $\begin{array}{l}0 \\
0\end{array}$ \\
\hline $\begin{array}{c}\text { Biacchiardi PM } \\
\text { [25] }\end{array}$ & RBMO 2011 & Cohort & 43 & $\begin{array}{l}\text { Lpic striping } \\
\text { and Bipolar }\end{array}$ & $\begin{array}{c}\text { AMH, Ovvol } \\
\text { FSH } \\
\text { Inhib E2 } \\
\text { AFC }\end{array}$ & 3,9 & $\begin{array}{c}0.0001 \\
\text { Unchanged } \\
\text { No SS } \\
\text { change }\end{array}$ \\
\hline Urman B [42] & RBMO 2013 & Cohort & 25 & Lpic stripping & $\begin{array}{l}\mathrm{AMH}, \\
\mathrm{AFC}\end{array}$ & 1,6 & 0.01 \\
\hline $\begin{array}{c}\text { Uncu G et al. } \\
{[16]}\end{array}$ & $\begin{array}{c}\text { HR } \\
2013\end{array}$ & Cohort & $\begin{array}{c}30 \\
30 \text { healthy }\end{array}$ & Lpic stripping & $\begin{array}{l}\mathrm{AMH}, \\
\mathrm{AFC}\end{array}$ & 1,6 & $\begin{array}{l}0.02 \\
0.01\end{array}$ \\
\hline $\begin{array}{c}\text { Ercan CM et al. } \\
{[28]}\end{array}$ & $\begin{array}{c}\text { EJ OG RB } \\
2011\end{array}$ & Prospective & 36 & Lpic stripping & $\begin{array}{c}\text { AFC } \\
\text { Doppler Flow } \\
\text { AMH }\end{array}$ & 3 & $\begin{array}{c}\text { Significantly low } \\
\text { Same } \\
\text { No SS change }\end{array}$ \\
\hline $\begin{array}{c}\text { Tsolakides et al. } \\
\text { [26] }\end{array}$ & $\begin{array}{c}\text { FS } \\
2010\end{array}$ & PRT & 20 & $\begin{array}{l}\text { Lpic stripping } \\
\text { Laser CO2 }\end{array}$ & $\begin{array}{c}\text { AMH, } \\
\text { AFC } \\
\text { FSH LH E2 }\end{array}$ & 6,12 & $\begin{array}{l}0.026 \\
0.002\end{array}$ \\
\hline $\begin{array}{c}\text { Asgari Z et al. } \\
{[37]}\end{array}$ & Arch Gyn 2015 & PRT & 109 & $\begin{array}{l}57 \text { bipolLpic } \\
52 \text { sutLpic }\end{array}$ & $\begin{array}{l}\text { AMH } \\
\text { FSH }\end{array}$ & 3 & $\begin{array}{l}\text { Signific higher } \\
\text { Signific higher }\end{array}$ \\
\hline
\end{tabular}

Table 1 summarizes the most recent studies on unilateral endometrioma surgery and haemostasis techniques effect on ovarian reserve. In all articles there is significant decrease in ovarian reserves, independently what technique has been used. Laparoscopic stripping was a common and basic way of endometrioma pseudocapsule removal among all studies, being detrimental to healthy ovarian tissue prior to any haemostatic technique to be followed. Three meta- analysis and systematic reviews have been published on Endometrioma Surgery and Haemostasis techniques and their effect on ovarian reserves. All 3 meta-analysis were reviewing the circulating AMH before and after surgery among selected PRCTs [32]. Selected 8 out of 21 studies, polled 237 patients, found a significant post-operative fall in circulating $\mathrm{AMH}$, concluding that endometrioma excision has negative impact on ovarian reserves. Somigliana E et al. [41] selected 11 out of 47 studies, pooled 344 patients, also showed endometrioma surgery related ovarian reserve damage. They concluded that no further research needed, proposing the investigation of innovative endometrioma surgical measures.

Another meta-analysis of 7RCTs searching for laparoscopic ovarian cystectomy versus fenestration/coagulation or laser vaporization for the treatment of endometriomas, demonstrated significantly lower risk of recurrence of signs and symptoms for laparoscopic cystectomy [RR: 0.29; 95\% CI: 0.15-0.55; $\mathrm{I}^{2}=0 \%$; $\mathrm{p}<0.001]$ The chance of pregnancy was significantly higher for cystectomy compared with fenestration/coagulation (RR: 2.64; 95\% CI: 1.49-4.69; $\mathrm{I}^{2}=0 \%$; $\mathrm{p}<0.001$ ), but not laser vaporization (RR: $0.92 ; 95 \%$ CI: $0.30-2.80 ; \mathrm{p}=0.89$ ). However, there were inadequate data for the meta-analysis of ovarian reserve. Authors concluded that further studies are needed to clarify the effect of these surgical approaches on ovarian reserve [15].

In a more recent systematic review and meta-analysis of the haemostatic effect on ovarian reserve after laparoscopic endometrioma excision, 4 out of 6 studies were selected and pooled 213 patients. Haemostasis by suturing the cyst bed was unclear whether preserves more healthy ovarian tissue than bipolar diathermy coagulation. Moderate quality of evidence favours the application of a haemostatic sealant and low quality of evidence favours suturing over bipolar diathermy. Sealants could be better than bipolar but since it's human or bovine plasma derived product, the risk of viral transmission was of high concern. Authors concluded that bipolar should be 


\section{Global Journal of Reproductive Medicine}

cautiously limited, even avoided [42,43] selected 13 out of 24 studies pooled 597 patients underwent endometrioma surgery, considered as determining marker of ovarian reserve the pre and post-operative AFC. Although lower AFC was found in affected ovary after surgery did not reach statistical significance. Concluding that AFC is not reduced after surgery.

\section{Discussion}

Endometrioma surgery and haemostatic method can negatively affect ovarian reserves. The size of the endometrioma and the surgical technique are the most determining factors preserving ovarian function. Stripping the endometrioma pseudocapsule is detrimental for healthy ovarian tissue, reduces the risk of recurrence, however, not appropriate for infertility patients undergoing ART. Reproductive surgery should respect maximum possible healthy ovarian tissue increasing the chances of good quality and quantity of oocytes. The haemostatic method used during endometrioma surgery also affects negatively ovarian reserve. It seems that among all haemostatic modalities, the plasma energy causes the minimum damage to healthy ovarian tissue. Coagulation of the entire endometrioma bed should never be performed. The first operation is probably the most crucial for fertility prognosis. Incomplete and/or unduly traumatic procedures probably, greatly reduce the ovarian reserve and chance of spontaneous pregnancy and increase the risk of endometrioma recurrence and /or persistence [10] Fenestration and laser vaporization of an endometrioma seems to minimally destruct the healthy ovarian tissue, offering the best surgery treatment option to infertility patients.

\section{Conclusion}

Endometrioma pseudo-capsule stripping and bipolar diathermy for haemostasis reported a statistically significant decrease inovarian volume, AFC and increase in $\mathrm{AMH}$, being more detrimental to healthy ovarian tissue when compared to fenestration andlaser ablation. Endometrioma surgery technique should be carefully selected especially in infertility cases, high risk patients for premature ovarian failure and bilateral endometriomas.

\section{References}

1. Gordts S, Campo R, Brosens I (2014) Hysteroscopic diagnosis and excision of myometrial cystic adenomyosis. Gynecol Surg 11(4): 273278.

2. Yanushpolsky EH, Best CL, Jackson KV, Clarke RN, Barbieri RL, et al. (1998) Effects of endometriomas on ooccyte quality, embryo quality, and pregnancy rates in in vitro fertilization cycles: a prospective, casecontrolled study. J Assist Reprod Genet 15(4): 193-197.

3. Suzuki T, Izumi S, Matsubayashi H, Awaji H, Yoshikata K, et al. (2005) Impact of Ovarian Endometrioma on Oocytes and Pregnancy Outcome in in Vitro Fertilization. Fertility and Sterility 83(4): 908-913.

4. Kumbak B, Kahraman S, Karlikaya G, Lacin S, Guney A (2008) In vitro Fertilization in Normoresponder Patients with Endometriomas: Comparison with Basal Simple Ovarian Cysts. Gynecol Obstet Invest 65(3): 212-216
5. Almog B, Sheizaf B, Shalom-Paz E, Shehata F, Al-Talib A, et al. (2010) Effects of excision of ovarian endometrioma on the antral follicle count and collected oocytes for in vitro fertilization. Fertil Steril 94(6): 23402342.

6. Banerjee SK, Ballard KD, Wright JK (2008) Endometriosis as a marker of disease severity. J minim invasive gynecol 15(5): 536-540.

7. Jenkins S, Olive DL, Haney AF (1986) Endometriosis: pathogenetic implications of the anatomic distribution. Obstet Gynecol 67(3): 335338.

8. Redwine DB (1999) Ovarian endometriosis: a marker for more extensive pelvic and intestinal disease. Fertil Steril 72(2): 310-315.

9. Busacca M, Vignali M (2003) Ovarian endometriosis: from pathogenesis to surgical treatment. Curr Opin Obstet Gynecol 15(4): 321-326.

10. Vercellini P, Busacca M, Aimi G, Bianchi S, Frontino G, et al. (2002) Lateral distribution of recurrent ovarian endometriotic cysts. Fertil Steril 77(4): 848-849.

11. Ferrero S, Abbamonte LH, Anserini P, Remorgida V, Ragni N (2005) Future perspectives in the medical treatment of endometriosis. Obstet Gynecol Surv 60(12): 817-826.

12. Donnez J, Nisolle-Pochet M, Clerckx-Braun F, Sandow J, CasanasRoux F (1989) Administration of nasal Buserelin as compared with subcutaneous Buserelin implant for endometriosis. Fertil Steril 52(1): 27-30.

13. Donnez J, Pirard C, Smets M, Jadoul P, Squifflet J (2004) Surgical management of endometriosis. Clin Obstet Gynaecol 18(2): 329-348.

14. Alborzi S, Momtahan M, Ebrahim Parsanezhad M, Dehbashi S, Zolghadri J, et al. (2004) A Prospective, Randomized Study Comparing Laparoscopic Ovarian Cystectomy Versus Fenestration and Coagulation in Patients With Endometriomas. Fertil Steril 82(6): 1633-1637.

15. Dan H, Limin F (2013) Laparoscopic ovarian cystectomy versus fenestration/coagulation or laser vaporization for the treatment of endometriomas: a meta-analysis of randomized controlled trials. Gynecol Obstet Invest 76(2): 75-82.

16. Uncu G, Kasapoglu I, Ozerkan K, Seyhan A, Oral Yilmaztepe A, et al. (2013) Prospective assessment of the impact of endometriomas and their removal on ovarian reserve and determinants of the rate of decline in ovarian reserve. Hum Reprod 28(8): 2140- 2145.

17. Chen Y, Pei H, Chang H, Chen H, Wang H, et al. (2014) The impact of endometrioma and laparoscopic cystectomy on ovarian reserve and the exploration of related factors assessed by serum anti-Mullerian hormone. J Ovarian Res 7: 108.

18. Ferraretti AP, La Marca A, Fauser BC, Tarlatzis B, Nargund G, et al (2011) ESHRE consensus on the definition of 'poor response' to ovarian stimulation for in vitro fertilization: the Bologna criteria. Hum Reprod 26(7): 1116-1124.

19. La Marca A, Broekmans FJ, Volpe A, Fauser BC, Macklon NS, et al. (2009) Anti-Mullerian hormone (AMH): what do we still need to know? Hum Reprod 24(9): 2264-2275.

20. Hansen KR, Hodnett GM, Knowlton N, Craig LB (2011) Correlation of ovarian reserve tests with histologically determined primordial follicle number. Fertil Steril 95(1): 170-175.

21. Broer SL, Dólleman M, van Disseldorp J, Broeze KA, Opmeer BC, et al. (2013) Prediction of an excessive response in in vitro fertilization from patient characteristics and ovarian reserve tests and comparison in subgroups: an individual patient data meta-analysis. Fertil Steril 100(2): 420-429.

22. Broer SL, van Disseldorp J, Broeze KA, Dolleman M, Opmeer BC (2013) Added value of ovarian reserve testing on patient characteristics in the 


\section{Global Journal of Reproductive Medicine}

prediction of ovarian response and ongoing pregnancy: an individual patient data approach. Hum Reprod Update 19(1): 26-36.

23. van Disseldorp J, Lambalk CB, Kwee J, Looman CW, Eijkemans MJ, et al. (2010) Comparison of inter- and intra-cycle variability of antiMullerian hormone and antral follicle counts. Hum Reprod 25(1): 221227

24. Rustamov 0, Smith A, Roberts SA, Yates AP, Fitzgerald C, et al. (2014) The measurement of anti-Müllerian hormone: a critical appraisal. J Clin Endocrinol Metab 99(3): 723-732.

25. Biacchiardi CP, Piane LD, Camanni M, Deltetto F, Delpiano EM, et al. (2011) Laparoscopic stripping of endometriomas negatively affects ovarian follicular reserve even if performed by experienced surgeons. Reprod Biomed Online 23(6): 740-746.

26. Tsolakidis D, Pados G, Vavilis D, Athanatos D, Tsalikis T, et al. (2010) The impact on ovarian reserve after laparoscopic ovarian cystectomy versus three-stage management in patients with endometriomas: a prospective randomized study. Fertil Steril 94(1): 71-77.

27. Hwu YM, Wu FS, Li SH, Sun FJ, Lin MH, et al. (2011) The impact of endometrioma and laparoscopic cystectomy on serum anti-Mullerian hormone levels. Reprod Biol Endocrinol 9: 80.

28. Ercan CM, Sakinci M, Duru NK, Alanbay I, Karasahin KE, et al. (2010) Antimullerian hormone levels after laparoscopic endometrioma stripping surgery. Gynecol Endocrinol 26(6): 468-472.

29. Hirokawa W, Iwase A, Goto M, Takikawa S, Nagatomo Y, et al. (2011) The post-operative decline in serum anti-Mullerian hormone correlates with the bilaterality and severity of endometriosis. Hum Reprod 26(4) 904-910.

30. Kitajima M, Khan KN, Hiraki K, Inoue T, Fujishita A, et al. (2011) Changes in serum anti-Mullerian hormone levels may predict damage to residual normal ovarian tissue after laparoscopic surgery for women with ovarian endometrioma. Fertil Steril 95(8): 2589-2591.

31. Lee DY, Young Kim N, Jae Kim M, Yoon BK, Choi D (2011) Effects of laparoscopic surgery on serum anti-Mullerian hormone levels in reproductive-aged women with endometrioma. Gynecol Endocrinol 27(10): 733-736.

32. Raffi F, Metwally M, Amer S (2012) The impact of excision of ovarian endometrioma on ovarian reserve: a systematic review and metaanalysis. J Clin Endocrinol Metab 97(9): 3146-3154.

33. Celik HG, Dogan E, Okyay E, Ulukus C, Saatli B, et al. (2012) Effect of laparoscopic excision of endometriomas on ovarian reserve: serial changes in the serum anti-Mullerian hormone levels. Fertil Steril 97(6): 1472-1478.

34. Ferrero S, Scala C, Racca A, Calanni L, Remorgida V, et al. (2015) Second surgery for recurrent unilateral endometriomas and impact on ovarian reserve: a case-control study. Fertil Steril 103(5): 1236-1243.

35. Zaitoun M, Zaitoun M, EL Behery M (2013) Comparing long term impact on ovarian reserve between laparoscopic ovarian cystectomy and open laprotomy for ovarian endometrioma. J Ovarian Res 6(1): 76.

36. Li CZ, Liu B, Wen ZQ, Sun Q (2009) The impact electrocoagulation on ovarian reserve after laparoscopic excision of ovarian cysts: a prospective clinical study of 191 patients. Fertil Steril 92(4): 14281435.

37. Asgari Z, Rouholamin S, Hosseini R, Sepidarkish M, Hafizi L, et al. (2015) Comparing ovarian reserve after laparoscopic excision of endometriotic cysts and hemostasis achieved either by bipolar coagulation or suturing: a randomized clinical trial. Arch Gynecol Obstet 293(5): 1015-1022.

38. Kang JH, Kim YS, Lee SH, Kim WY (2015) Comparison of hemostatic sealants on ovarian reserve during laparoscopic ovarian cystectomy. Eur J Obstet Gynecol Reprod Biol 194: 64-67.

39. Roman H, Pura I, Tarta O, Mokdad C, Auber M, et al. (2011) Vaporization of ovarian endometrioma using plasma energy: histologic findings of a pilot study. Fertil Steril 95(5): 1853-1856.

40. Roman H, Auber M, Mokdad C, Martin C, Diguet A, et al. (2011) Ovarian endometrioma ablation using plasma energy versus cystectomy: a step toward better preservation of the ovarian parenchyma in women wishing to conceive. Fertil Steril 96(6): 1396-1400.

41. Somigliana E, Berlanda N, Benaglia L, Vigano P, Vercellini P, et al. (2012) Surgical excision of endometriomas and ovarian reserve: a systematic review on serum antimu"llerian hormone level modifications. Fertil Steril 98(6): 1531-1538.

42. Ata B, Turkgeldi E, Seyhan A, Urman B (2015) Effect of Hemostatic Method on Ovarian Reserve Following Laparoscopic Endometrioma Excision; Comparison of Suture, Hemostatic Sealant, and Bipolar Dessication. A Systematic Review and Meta-Analysis. J Minim Invasive Gynecol 22(3): 363-372.

43. Muzii L, Di Tucci C, Di Feliciantonio M, Marchetti C, Perniola G, et al. (2014) The effect of surgery for endometrioma on ovarian reserve evaluated by antral follicle count: a systematic review and metaanalysis. Hum Reprod 29(10): 2190-2198.

\section{Your next submission with Juniper Publishers will reach you the below assets}

- Quality Editorial service

- Swift Peer Review

- Reprints availability

- E-prints Service

- Manuscript Podcast for convenient understanding

- Global attainment for your research

- Manuscript accessibility in different formats

( Pdf, E-pub, Full Text, Audio)

- Unceasing customer service

Track the below URL for one-step submission https://juniperpublishers.com/online-submission.php 